\title{
ЕТНОКОНЦЕПТ УКРАÏНА ЯК ФРАГМЕНТ КОГНІТИВНОГО ОСВОЄННЯ ВСЕСВІТУ
}

Шарманова Н. М. Етноконцепт Украӥна як фрагмент когнітивного освоєння Всесвіту.

У статті висвітлюються когнітивні механізми освоєння дійсності шляхом вербалізації національно маркованого концепту „Україна» на матеріалі мовних кліше. Концепт Украӥна позначений найвищим ступенем етноцентричності і становить національний духовний макроконцепт. Фонова інформація відсилає реципієнта до прецедентних ситуацій, притаманних українській культурі.

Ключові слова: етноконцепт, концептуальна картина світу, мовні кліше, когнітивна база, ксеноетнонім.

Шарманова Н. Н. Этноконцепт Украина как фрагмент когнитивного освоения Вселенной.

В статье рассматриваются когнитивные механизмы освоения действительности путём вербализации национального концепта Украина на материале языковых клише. Концепт Украина обозначен самой высшей степенью этноцентричности и является национальным духовным макроконцептом. Фоновая информация отсылает реципиента к прецедентным ситуациям, свойственным украинской культуре.

Ключевые слова: этноконцепт, концептуальная картина мира, языковое клише, когнитивная база, ксеноэтноним.

Sharmanova N. M. Ethnoconcept Ukraine as a subject of cognitive mastering of the Universe.

The article shows the cognitive mechanisms of development of the validity through verbalization of national marked concept Ukraine on a material of language clichés. Concept Ukraine is meant by the highest level of ethnocentrism and it makes the national spiritual macroconcept. The background information sends recipient to the precendent situations, which are peculiar to Ukrainian culture.

Key words: ethnoconcept, conceptual picture of the Universe, language clichés, cognitive base, ksenoethnonim.

Дослідження етнокультурного компонента української літературної мови - важливий крок до розуміння національної свідомості, методології етнолінгвістики та один із напрямків сучасної славістики. Універсальні складові цілісної моделі світу відбиваються крізь мову, відображаючи іiі духовну культуру, національні орієнтири і стереотипи. Етнічна специфіка мови визначається “насамперед психотипом іï носія, який (психотип), у свою чергу, формується в процесі історичного, геополітичного й культурного розвитку етносу" $[2,245]$.

Специфічним змістом співвіднесеності носія мови 3 етнічною свідомістю, яка відтворює загальний дух мови, позначені унікалії, що містить кожна національна культура. Достатньо актуальною сьогодні “загальнославістичною тенденцією слід вважати розгляд глотогенезу кожної зі слов'янських мов як окремого своєрідного історичного явища, при цьому кожна мова має як шерег рис, спільних з кількома або всіма слов'янськими 
мовами, так і унікальні особливості, що з'явилися протягом незалежного усамостійненого розвитку" $[10,198]$. Так, мова є репрезентантом ментальності й детермінатором процесу етнічної соціалізації індивіда.

У сучасній науковій літературі виокремлюється декілька підходів до дефініції “концепт”: філософський (Ж. Дельоз, Ф. Гаватарі), логікофілософський (Ч. Пірс, Г. Фреге), лінгвістичний (В. Гак, В. Звегінцев, О. Тараненко), лінгвокультурологічний (А. Вежбицька, Ю. Степанов, Г. Токарев, В. Ужченко), когнітивний (О. Кубрякова, 3. Попова, І. Стернін), психолінгвістичний (О. Селіванова, І. Штерн, Л. Лисиченко), культурологічний і літературознавчий (Л. Грузберг, В. Зусман та ін.).

Під концептами розуміють інформаційну структуру свідомості, різносубстратну, певним чином організовану одиницю пам'яті, яка містить сукупність знань про об'єкт пізнання, вербальних і невербальних, набутих шляхом взаємодії механізмів пізнання $[8,236]$. Концепти національної ідентичності формують модус світосприйняття (А. Вежбицька, Л. Виготський, Д. Гудков, Дж. Лакофф, О. Лосєв, В. Маслова, О.Потебня, Б. Уорф та ін.).

Концептуалізація світу грунтується не лише на універсаліях, а й на етнічному компоненті, власне, на етноконцептах як структурах свідомості, що мають „спільні для представників певного етносу складники” [8, 231]. Етнокультурний простір інтерпретується через культурні тексти (міні- i макро-) як прецеденти, котрі загалом „,є полем презентації концепту культури" [7, 30].

Аналізуючи слово-символ как фразеологічну детермінанту, Д.Ужченко виділяє серед базових такі концепти: “Хата", “Поріг”, “Рушник”, “Вогонь”, “Дорога”, “Чоботи”, “Чумак”, “Калина”, “Осина” [9, 289].

Концепт “Україна” позначений найвищим ступенем етноцентричності. Вербальною оболонкою його є різні мовні кліше - фраземи, слогани тощо: Прийдуть з Украӥни верби і тополі (В. Симоненко); Вітер з України (С. Руданский); Родом з України (інформаційна передача на НТРК УТ-1). Персоніфікація образу України пов’язана з духовним генотипом українського народу й близькими за смислом архетипами, етнічними образами, що супроводжують кожного українця з дитинства. Це краще за все відображено в знакових одиницях - афоризмах, пареміях, політичних гаслах тощо репрезентантах авторського світовідчуття чи українського постфольклору, релевантні властивості яких сприяють створенню мовленнєвої інтелектуалізації, пов’язаної з інтерактивною моделлю дискурсу.

Указані мовні кліше співвідносяться з прецедентними феноменами ( $\epsilon$ прецедентними текстами), що спираються на фонові знання комунікантів, визначають світ норми, закономірностей, узагальнень і стратегію моральної поведінки кожної людини й соціуму загалом. Семантичне становлення афористичного вислову і паремії починається переважно з метафоричного переосмислення реальної дійсності, унаслідок чого лексичні компоненти деактуалізуються, прирощують конотацію, яка відтворює зв’язок 
асоціативно-образного підгрунтя з культурою, іiі еталонами, символами, стереотипами $[4,71-73]$ і розглядається як знання, джерело когнітивного освоєння Всесвіту.

Мета нашої розвідки полягає у 3’ясуванні сутності етноконцепту "Україна" як прецедентного номена й лінгвокультурного тексту. Для реалізації мети визначено такі завдання: 1) розкрити когнітивні механізми та етапи вербалізації національно маркованого концепту; 2) дослідити специфіку етноментального мислення крізь призму концептуального аналізу на матеріалі мовних кліше (слоганів, афоризмів, паремій).

Поєднання когнітивного й функціонального підходів дозволяє осмислити сутність прецедентних текстів через звернення до структур ментефактів (концептів) і конвенціональних способів їх репрезентації в свідомості комуніканта. Категорії, вербалізовані в “лозунговій" картині світу (Ю. Левін), розкривають взаємозв'язок між репрезентацією мовного знання та його обробкою. Смисл афоризму (паремії) може бути інтерпретовано за умови експлікації всіх його компонентів, що є одночасно й етапами деривації, а саме: 1) перцептивна ситуація (відображення нормативниых уявлень); 2) етномовний образ (гештальт, фрейм), який визначається перцептивною ситуацією і виокремлений із неї їі ознакою; 3) когнітивний аналог образу як когнітивне профіліювання концепту (тобто ситуація, що містить абстраговані з образу елементи та взаємозв'язки між ними у вигляді пропозицій); 4) ірадіювання асоціацій, пов'язане зі знаннями носіїв мови про перцептивну ситуацію, оцінюванням елементів мовної одиниці (емоційнооцінне профіліювання концепту).

Етнонім "Україна" сам по собі є національним духовним макроконцептом, який може тлумачитися як складова культурного симболарію (Токарев Г.), що визначає індивідуальну когнітивну картину світу й фонові, енциклопедичні знання комуніканта на рівні етносвідомості: Украӥно! Доки жити буду, доти відкриватиму тебе (В. Симоненко); Найгостріше слово - Украӥна (О. Теліга); Калино моя - Украӥно! В твоїм кущзі - я кетяг багряний! (І. Жиленко), Зажурилась Україна - така ї̈ доля (Т. Шевченко); $C$ боротьба за долю Украӥни (Л. Костенко); Україно! Ти для мене диво, ти моя молитва, ти моя розпука вікова (В. Симоненко). Лінгвоментальний аспект розкривається при співвіднесенні ключового концепту “Україна" 3 асоціативними рядами понять: 1) калина - кетяг; 2) доля - боротьба; 3) диво - молитва; 4) життя - слово тощо.

Етноконцепт "Україна" співвідноситься 3 концептуальномовною картиною світу, із макроконцептом "Універсум" як узагальненою світобудовою загалом: Сонце $і$ пісня вгорі - це моя Украӥна (В. Сосюра); Других Украӥн не шукає мій зір (М. Вінграновський); Архіпелаг поснулих хуторів це Україна (Є. Маланюк). Крім того, основний концепт спирається на етноніми, що розкривають виразно національні ментефакти: Для Украӥни вічним заборолом постане гордо Запорізька Січ (Вс. Ткаченко); Київ - нев- 
мируще серие України (П. Тичина); Украӥнці - бунтівний народ. Еволюиійно не змінився з часів Київської Русі (О.Чорногуз).

Опис ментальної дійсності, який подає етноконцепт, неможливий без таких його диференціаторів, як динамічний характер, багатовимірність i множинність складників, що знайшло відображення в мовних одиницях сучасного художнього й політичного дискурсу, наприклад: Раби зростають до синів своєї Украӥни-матері; У білій стужі серие Украӥни (В. Стус); Скільки й живе Україна - повно в ній удів, так ніби записано в книгах віщих навіки бути ій удовиџькою землею; Спаситель прогнав торгуючих з храму, а сьогодні вся Украӥна - збезчещений храм з непрогнаними (П. Загребельний). Виникає інтерференція культурних кодів як своєрідний міжкультурний діалог, де наявна прозора актуалізація інших концептів духовних (інтелектуальних, моральних, правових, релігійних, філософських). Універсальні категорії “час" і “простір" набувають цікавого звучання - сьогодні вся Україна). Фонова інформація, репрезентантом якої є базовий етноконцепт, відсилає реципієнта до прецедентных ситуацій, притаманних тільки українській національній культурі - довготривалому періоду етноциду під гнітом трьох імперій або сучасному (resp. постмодерністському, постколоніальному) стану українського соціуму. Відтак, етноконцепт "Україна" дає вихід на інші етнічні концепти й образи: політичні, наприклад, біла стужа, удовиџька земля; економічні, наприклад, Україна - збезчещений храм тощо.

Викривлене уявлення створюється доволі в непоодиноких випадках 3 опорою на спорадичну апперцепцію комуніканта в парадоксальных афоризмах: Найбільша пральня Украӥни - ие ї телебачення (П.Загребельний). Такі афоризми відбивають рефлексію реальності в свідомості перш за все окремого індивіда, ніж в етносвідомості. Загалом же деривацію пареміологічних одиниць, їх співвіднесеність із реальністю можна оцінювати як творчий комунікативний акт, де асоціації залежать від різних факторів, „починаючи з миттєвого стану мовної особистості й завершуючи найтиповішими національними стереотипами" [3, 170].

Прецедентні тексти 3 етноконцептом "Україна" як віддзеркалення стереотипів мають універсальну адресацію й реалізують комунікативні завдання повідомлення нових знань чи апеляції до наявних у когнітивній базі учасника комунікативного акту [5, 72-85]. Універсальність комунікативної ситуації визначається тим, що кожен адресат має можливість ототожнити себе з суб'єктом ситуації. Категорію суб'єктивності в афоризмах і пареміях розглядаємо крізь призму категорії узагальненого суб'єкта. Формальнограматичним засобом вираження названої категорії найчастіше виступає Н. в. особових і присвійних займенників: Я люблю тебе, Украӥно, степом, Дніпром $і$ Тарасом (М. Вінграновський); Моя Украӥно, недоле моя (Т. Осьмачка); Вулканна моя Україна (І. Драч); Моя країна - Україна (назва науково-популярного видання). Значним смисловим навантаженням 
позначені вислови, у яких когніція “почуття" позначена потенційною суб'єктивністю: Пропікає душу Украӥна; Сміється божевільна Украӥна у смертнім леті на чужім крилі (В. Стус).

Дискурс національної хвилі на зламі різних епох, політичних пристрастей відображено в манері спілкування влади з народом. Це, по суті, може являти собою або відбиття категорії посесивності, або PR- технології (загравання з масами, відверте / навмисне інтимізування стосунків народного лідера з народом тощо): Моя Україно (із звертань Президента В.Ющенка); Ми не хочемо жити в УРКӒ̈ні (слоган на плакатах мітингуючих під час революційних подій 2004 року). Прагматика спілкування побудована, як бачимо, іноді на мовній грі, коли навмисне зближуються близькозвучні, але абсолютно різні за семантичним наповненням лексеми і подається декодування актуальних, суспільно вагомих смислів (Україна - УРКӒ̈на).

Виразно національним пафосом такі мовні кліше позначені на противагу іншим гаслам, які вербалізують когнітивні уламки, що в сумі ніколи не можуть дати єдине поняття, суцільний етнічний образ держави, нації: Донбасс - это Янукович; Закарпатье - это Балога; Днепропетровск - это Тимошенко (інформаційний бюлетень “На Самом Деле”). Окреслене вище розуміння сутності концепту “Україна” дає вихід на додаткові його диференціатори. Зокрема, тут варто зупинитися на т.зв. "ксеностереотипі”, що постає в свідомості носіїв інших культур, які мешкають в Україні чи за їі межами як опозиція свій/ чужий: Україна - не Росія (назва книги Л. Кучми); Інша Україна: підміна понять (“Дзеркало тижня”, № 9, 814.03.2008). Етнічна номінація з яскраво вираженою пейоративністю представлена у висловах на зразок $M u$ - ледащзі жителі Хохляндї, хохли з обвислими вусами, куркулі $і$ підкуркульники, зрадники $і$ поліцаї, мазепиниі, петлюрівичі, бандерівизі. Нам нема місия на своїй землі. Ми самовбивці (В.Голобородько). Такий ксеностереотип детермінований рядом суб'єктивних, упереджених уявлень інших етносів про домінуючі риси національного українського характеру як “чужої” етнічної групи. Наведена неофіційна назва України й українців розглядається як явище ксенофобіï, а вербалізація “ксеноетнонімів" - мовленнєва стереотипізація, яка грунтується на культурно-історичному й соціальному конфліктах.

Описані вище мовні факти засвідчують, що вербалізація етноконцепту “Україна" здійснюється в чотири етапи: співвіднесення концепту з етимоном відповідного слова; формування внутрішньої форми - смислового центра концепту-образу; символізація значення; міфологізація концепту як дія символу в парадигмі культури [1].

Таким чином, прецедентні тексти - афоризми, паремії тощо - виступають результатом когнітивної й мовленнєвої діяльності людини, а відтак легко входять в індивідуальну й масову (національну) когнітивну бази, що пов'язується зі складними ментальними механізмами кодування й декодування інформації про реальний / ірреальний світ та ії використання в кому- 
нікації. Етноконцепт “Україна” узагальнює комплекс символічних значень iз духовними, астральними, світоглядними національними образами й мікроконцептами: Універсум, Батьківщина, нація, земля, доля, життя, мати тощо - та протиставляється ксеностереотипам, окресленим поняттями "неХохляндія", “не-Росія”, "не-Малоросія", невідантропонімна автономія. Базовий лінгвоконцепт є одночасно складовою когнітивного освоєння світу й репрезентантом національної самоідентичності.

\section{Література}

1.Алефиренко Н. Ф. Когнитивно-семиологическая лингвокультурология: Истоки и методологические основы / Н. Ф. Алефиренко // Знание. Язык. Культура: [материалы Междунар. научной конф.] - Тула : Петровская Гора, 2007. - С. 3-8.

2. Жайворонок В. В. Українська етнолінгвістика: нариси / В. В. Жайворонок - К. : Довіра, 2007. - 263 с.

3. Красных В. В. Этнопсихолингвистика и лингвокультурология : [курс лекцій] / В. В. Красных - М. : Гнозис, 2002. - 284 с.

4. Маслова В. А. Культурно-национальная специфика русской фразеологии / В. А. Маслова // Культурные слои во фразеологизмах и дискурсивных практиках [отв. ред. В. Н. Телия]. - М. : Языки славянской культуры, 2004. - С. 69-76.

5. Радзієвська Т. В. Текст як засіб комунікації / Т. В. Радзієвська / НАН України Ін-т української мови; [відп. ред. М. М. Пещак]. - К., 1998. - 194 с.

6. Телия В. Н. Первоочередные задачи и методологические проблемы исследования фразеологического состава языка в контексте культуры / В. Н. Телия // Фразеология в контексте культуры [отв. ред. В. Н. Телия]. - М. : Языки рус. культуры, 1999. - С. 13-24.

7. Токарев Г. В. Семиотика : [учеб. пособие] / Г. В. Токарев - Тула : Изд-во Тульского гос. пед. ун-та им. Л.Н.Толстого, 2007. - 147 с.

8. Селіванова О. О. Нариси з української фразеології (психокогнітивний та етнокультурний аспекти): [монографія] / О. О. Селіванова - К.-Черкаси : Брама, 2004. $-276 \mathrm{c}$.

9. Ужченко В. Д. Фразеологія сучасної української мови / Ужченко В. Д., Ужченко Д. В. - К. : Знання, 2007. -494 с.

10. Царук О. В. Українська мова серед інших слов'янських: етнографічні та граматичні параметри : [монографія] / О. В. Царук. - Дніпропетровськ : Наука і освіта, 1998. $-324 \mathrm{c}$.

11. Шарманова Н. М. Ментальний план афористичного світобачення (на матеріалі сучасної української афористики) / Н. М. Шарманова // Література. Фольклор. Проблеми поетики : зб. наук. праць. - К. : Акцент, 2005. - Вип. 21. Ч. 1. - С. 639-647. 